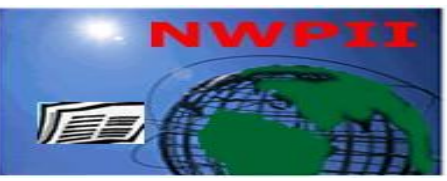

American Journal of Biomedical Sciences

ISSN: 1937-9080

nwpii.com/ajbms

\title{
Corn Silk Extracts as Scavenging Antioxidant in Oxidative Stress Induced Rabbits Using Corticosterone
}

\author{
Mathew Folaranmi Olaniyan*, Elizabeth Moyinoluwa Babatunde
}

Department of Medical Laboratory Science, Achievers University, Owo, Ondo state, Nigeria

"Corresponding Author

Mathew Folaranmi Olaniyan

Department of Medical Laboratory Science

Achievers University

Owo, Ondo state

Nigeria

GSM: +2348052248019; +2347033670802

Email : olaniyanmat@yahoo.com OR olaniyanmat@gmail.com

Received: 08 September 2015; | Revised: 12 January 2016; | Accepted: 23 January 2016

\begin{abstract}
Background to the Study: Corn silk contains phytochemicals of medical benefits such as proteins, vitamins, carbohydrates, $\mathrm{Ca}, \mathrm{K}, \mathrm{Mg}$ and $\mathrm{Na}$ salts, fixed and volatile oils, steroids such as sitosterol and stigmasterol, alkaloids, saponins, tannins, and flavonoids. Aim and Objective: This study aimed at the evaluation of the scavenging property of corn silk extract in oxidative stress induced rabbits using corticosterone. Materials and Methods: Fifteen rabbits divided into three experimental groups (A-Control, B-treated with aqueous extract and C-treated with methanolic extract) of 5 rabbits each were studied. The extract of the corn silk was obtained using methanol and water. Plasma Catalase, Superoxide dismutase and Glutathione peroxidase were estimated in the rabbits biochemically by spectrophotometry. The inducement of oxidative stress was done by administering corticosterone $(40 \mathrm{mg} / \mathrm{kg} / \mathrm{day})$ into the rabbits for 21 days before treatment. Results: The result obtained showed a significantly lower mean plasma value of Glutathione peroxidase, Catalase Test Croup B and C after inducement with corticosterone compared with the control with $\mathrm{P}<0.05$. A significantly higher mean plasma value of Glutathione peroxidase, Catalase was also obtained in test Croup B and $\mathrm{C}$ after treatment with corn silk extract following oxidative stress inducement with corticosterone than before the treatment with $\mathrm{P}<0.05$. Conclusion: The work has revealed significant scavenging anti-oxidative effect of methanolic and aqueous extract of corn silk following a significant oxidative stress induction using corticosterone in rabbits with reference to significant biochemical alteration in the plasma activities of Glutathione peroxidase and catalase.
\end{abstract}

Keywords: Corn silk extract, Catalase, Superoxide dismutase, Glutathione peroxidase, scavenging antioxidants. 


\section{Introduction}

Corn silk (Zea mays L.) refers to the stigmas from the female flowers of maize. Fresh corn silk resembles soft silk threads $10-20 \mathrm{~cm}$ long that are either light green or yellow-brown in color. Corn silk contains proteins, vitamins, carbohydrates, $\mathrm{Ca}, \mathrm{K}, \mathrm{Mg}$ and $\mathrm{Na}$ salts, fixed and volatile oils, steroids such as sitosterol and stigmasterol, alkaloids, saponins, tannins, terpenoids and flavonoids. The potential use is very much related to its properties and mechanism of action of its plant's bioactive constituents such as flavonoids and terpenoids [1,2]. There have been many reports on the biological activities of corn silk constituents. Methanol extracts of corn silk showed an antioxidative activity on the level of lipid peroxidation [3,4]. Volatiles from corn silk inhibited the growth of Aspergillus flavus, indicating that it has an antifungal activity [5].

Corn silk has been used in many parts of the world for the treatment of edema as well as for cystitis, gout, kidney stones, nephritis and prostatitis. Base on folk remedies, corn silk has been used as an oral antidiabetic agent in China for decades. However, in spite of its widespread use, the mechanisms underlying hypoglycemic activity of corn silk was not yet understood. Diuretic and uricosuric effect corn silk have also been reported [6]. The herbal drug Maydis stigma, style of female flower of Zea has also being used for the treatment of variety of diseases such as in urinary tract diseases, gonorrhea, benign prostatic hyperplasia, hypertension etc $[1,3]$.

Catalase is an enzyme responsible for the degradation of hydrogen peroxide. It is a protective enzyme present in nearly all animal cells. Superoxide dismutases are enzymes that alternately catalyze the dismutation (or partitioning) of the superoxide $\left(\mathrm{O}_{2}{ }^{-}\right)$radical into either ordinary molecular oxygen $\left(\mathrm{O}_{2}\right)$ or hydrogen peroxide $\left(\mathrm{H}_{2} \mathrm{O}_{2}\right)$. Superoxide is produced as a by-product of oxygen metabolism and, if not regulated, causes many types of cell damage. Hydrogen peroxide is also damaging, but less so, and is degraded by other enzymes such as catalase. Glutathione peroxidase (GPx) is the general name of an enzyme family with peroxidase activity whose main biological role is to protect the organism from oxidative damage. The biochemical function of glutathione peroxidase is to reduce lipid hydroperoxides to their corresponding alcohols and to reduce free hydrogen peroxide to water [7,8]. Lipid peroxidation refers to the oxidative degradation of lipids. It is the process in which free radicals "steal" electrons from the lipids in cell membranes, resulting in cell damage [9].

In many species, including amphibians, reptiles, rodents and birds, corticosterone is a main glucocorticoid, involved in regulation of energy, immune reactions, and stress responses. It is a natural corticoid with moderate glucocorticoid activity, some mineralocorticoid activity, and actions similar to cortisol except that it is not antiinflammatory. Corticosterone, a steroid hormone of the adrenal cortex; it affects carbohydrate, potassium, and sodium metabolism. It is usually classified as a glucocorticoid, but it also has slight mineralocorticoid activity [10].

This research work was designed to determine the scavenging anti-oxidative property of corn silk extract in oxidative induced rabbits using corticosterone.

\section{Materials and Methods}

\subsection{Subjects}

A total twenty (20) subjects were recruited in this study. Five subjects were served as methanolic test, five subjects as aqueous test, five subjects as control and five for emergency cases. The subjects were rabbits (Oryctolaguscuniculus) of about 5 weeks old.

\subsection{Description of the Study Areas}

Owo local government area lies on the Northern senatorial district of Ondo States, Nigeria within latitude $70100 \mathrm{~N}$ and longitude $70100 \mathrm{E}$, it is $150 \mathrm{~m}$ above sea level and enjoys abundant rainfall of over $1,500 \mathrm{~mm}$ annually, Plate 1 shows Owo Local Government Area in Ondo State.

\subsection{Grouping of experimental animals}


In order to have fair representation of weight categories in all the treatment groups, rabbits in each weight categories were distributed into three groups each, such that, the number of rabbits in each group is equal with different weight.

\subsection{Relabeling of rabbits according to treatment}

The rabbits were divided into three experimental group of 5 rabbits each.

Group A: five rabbits in which neither corticosterone nor water or methanol extract of corn silk was administered. This group serves as the control group.

Group B: five rabbits in which aqueous corn silk extract was administered everyday per $\mathrm{Kg}$ body weight for 21 days after 21 days of corticosterone administration.

Group C: five rabbits in which methanol extract of corn silk extract was administered everyday per $\mathrm{kg}$ body weight for 21 days after 21 days of corticosterone administration.

\subsection{Collection of corn silk}

Corn silk (dried cut stigmata of Zea mays. L.) used for this investigation were collected and were identified and authenticated and the voucher specimen was dried at room temperature. The aqueous and methanol extract were prepared.

\subsubsection{Corn silk aqueous extract}

Apparatus: steam bath, clean bucket, electronic weighing balance.

Procedure: $218.71 \mathrm{~g}$ of the air dried corn silk was weighed, and poured into a clean bucket.

About 7 liters of distilled water with temperature at $40^{\circ} \mathrm{C}$ was poured into the bucket with the corn silk.

It was allowed to stay for 72 hours at room temperature.

It was then sieved and distributed into beakers.

The water content was evaporated using a steam bath.

The extract gotten was then weighed.

\subsubsection{Corn Silk Methanol Extract \\ Method: Soxhlet Extraction.}

Principle: A solid material containing some of the desired compound is placed inside a thimble made from thick filter paper, which is loaded into the main chamber of the soxhlet extractor is now placed onto this flask. The solvent is heated to reflux. The solvent vapor travels up a distillation arm, and floods into the chamber housing the thimble of solid. The condenser ensures that any solvent vapour cools, and drips down into the chamber housing the solid material. The chamber containing the solid material is slowly filled with warm solvent. Some of the desired compound will then dissolve in the warm solvent. When the soxhlet chamber is almost full, the chamber is automatically emptied by a siphon side arm with the solvent running back down to the distillation flask. The thimble ensures that the solvent does not transport any solid material to the spill pot. This cycle may be allowed to repeat many times over hours or days. During each cycle, a portion of the non volatile compound dissolves in the solvent after many cycles the desired compound is concentrated in the distillation flask.

After the extraction the solvent was removed, typically by means of a rotary evaporator, yielding the extracted compound.

\subsubsection{Inducement of Oxidative stress and the Administration of Corn-Silk extract}

The inducement of oxidative stress was done by administering corticosterone $(40 \mathrm{mg} / \mathrm{kg} / \mathrm{day})$ into the rabbits for 21 days.

The extract was administered orally after 21 days of oxidative stress inducement at a dose of $400 \mathrm{mg} / \mathrm{kg} /$ day for 21 days.

Blood samples was collected from the rabbits before and after the inducement at the end of every week for three weeks and at the end of every week for 21 days post administration of the corn-silk extract following 21 days of corticosterone administration for the estimation of scavenging anti-oxidants which include: plasma Superoxide Dismutase, Glutathione Peroxidase and Catalase.

The control group was left untreated. Body weight was recorded at a week interval.

\subsection{Collection of Blood Samples}


Blood samples were collected after two weeks of acclamation. Blood was withdrawn through vein puncture from the earlobes of the rabbits using xylene to dilate the vein. Blood samples was collected into appropriate sample bottles, the blood was mixed, centrifuged, and the supernatant (plasma) was pipette out gently into plain bottles and was estimated instantly.

\subsection{Measurement of the weight of rabbits}

The weight of the rabbits were measured using a weighing balance before administration of extract.

Category A: five rabbits with average weight of $758 \mathrm{~g}$.

Category B: five rabbits with average weight of $1040 \mathrm{~g}$.

Category C: five rabbits with average weight of $984 \mathrm{~g}$.

\subsection{Biochemical methods}

\subsubsection{First method}

Measurement of Glutathione Peroxidase in the serum of test and control subjects was carried out using Glutathione Peroxidase Activity Colorimetric Assay Kit of Biovision.

Principle: Glutathione Peroxidase (GPx, EC 1.11.1.9) family of enzymes play important roles in the protection of organisms from oxidative damage. GPx converts reduced glutathione (GSH) to oxidized glutathione (GSSG) while reducing lipid hydroperoxides to their corresponding alcohols or free hydrogen peroxide to water. Several isozymes have been found in different cellular locations and with different substrate specificity. Low levels of GPx have been correlated with free radical related disorders. In BioVision's Glutathione Peroxidase Activity Assay, GPx reduces Cumene Hydroperoxide while oxidizing GSH to GSSG. The generated GSSG is reduced to GSH with consumption of NADPH by GR. The decrease of NADPH (easily measured at $340 \mathrm{~nm}$ ) is proportional to GPx activity. The assay can be used to measure all of the glutathione dependent peroxidases in plasma, erythrocyte lysates, tissue homogenates, and cell lysates with a detection sensitivity of $\sim 0.5 \mathrm{mU} / \mathrm{ml}$ of GPx in samples.

\subsubsection{Second method}

Measurement of Superoxide dismutase (SOD) in the serum of test and control subjects was carried out using Superoxide dismutase (SOD) Activity Colorimetric Assay Kit of Biovision.

Principle: Superoxide dismutase (SOD) is one of the most important antioxidative enzymes. It catalyzes the dismutation of the superoxide anion into hydrogen peroxide and molecular oxygen. The sensitive SOD assay kit utilizes WST-1 that produces a water-soluble formazan dye upon reduction with superoxide anion. The rate of the reduction with a superoxide anion is linearly related to the xanthine oxidase (XO) activity, and is inhibited by SOD (below). Therefore, the inhibition activity of SOD can be determined by a colorimetric method.

\subsubsection{Third method}

Measurement of Catalaze (CAT) in the serum of test and control subjects was carried out using Catalaze (CAT) Activity Colorimetric Assay Kit of Biovision.

Principle: Catalase (EC 1.11.1.6) is a ubiquitous antioxidant enzyme that is present in nearly all living organisms. It functions to catalyze the decomposition of hydrogen peroxide $\left(\mathrm{H}_{2} \mathrm{O}_{2}\right)$ to water and oxygen. BioVision's Catalase Assay Kit provides a highly sensitive, simple, direct and HTS-ready assay for measuring Catalase activity in biological samples. In the assay, catalase first reacts with $\mathrm{H}_{2} \mathrm{O}_{2}$ to produce water and oxygen, the unconverted $\mathrm{H}_{2} \mathrm{O}_{2}$ reacts with OxiRed ${ }^{\mathrm{TM}}$ probe to produce a product, which can be measured at $570 \mathrm{~nm}$ (Colorimetric method) or at $E x / E m=535 / 587 \mathrm{~nm}$ (fluorometric method). Catalase activity is reversely proportional to the signal. The kit detects high pico-unit of catalase in samples.

\subsection{Statistical analysis}

All data were analyzed by a one-way analysis of variance using the SPSS package, and the differences between means were established. The data represents means and standard deviations. The significant level of $5 \%(\mathrm{p}<0.05)$ was used as the minimum acceptable probability for the difference between the means. The results 
were expressed as Mean \pm SEM and all procedures were performed at $95 \%$ confidence Interval level.

\section{Results}

The result obtained showed no significant difference in the plasma value of superoxide dismutase, Glutathione peroxidase and Catalase in Test Croup B and C before inducement with corticosterone compared with the control with $\mathrm{P}>0.05$. (Tables 1, 2 and 4)

The result obtained showed a significantly lower mean plasma value of Glutathione peroxidase, Catalase Test Croup B and C after inducement with corticosterone compared with the control with $\mathrm{P}<0.05$, however, there was no significant difference in the mean value of superoxide dismutase in test Croup B and C after inducement with corticosterone compared with the control with $\mathrm{P}>0.05$ (Tables 2,3 and 4).

The result obtained showed a significantly higher mean plasma value of Glutathione peroxidase, Catalase in Test Croup B and C after treatment following inducement with corticosterone than before the treatment with $\mathrm{P}<0.05$. however, there was no significant difference in the mean plasma value of superoxide dismutase in test Croup B and C after treatment following the administration with corticosterone compared with the mean value before treatment with $\mathrm{P}>0.05$. (Tables 2,3 and 4).

Table 1. Below shows the serum value of Superoxide Dismutase, Glutathione Peroxidase and Catalase in the rabbits before inducement and treatment.

\begin{tabular}{lllll}
\hline Subjects & Superoxide & Glutathione & Catalase & Weight \\
& Dismutase, & Peroxidase & & \\
& & & U/mL & (grams) \\
& U/ml & (U/L) & & \\
\hline $\begin{array}{l}\text { Control Group A(Group not induced or } \\
\text { treated) }\end{array}$ & $151 \pm 11.4$ & $207 \pm 6.2$ & $7.3 \pm 0.8$ & $1013 \pm 100.8$ \\
\hline $\begin{array}{l}\text { Group B for treatment with Aqueous } \\
\text { Extract }\end{array}$ & $162 \pm 11.2$ & $198 \pm 5.3$ & $6.8 \pm 0.4$ & $950 \pm 104.1$ \\
\hline $\begin{array}{l}\text { Group C for treatment with ethanolic } \\
\text { Extract }\end{array}$ & $157 \pm 8.9$ & $200 \pm 10.1$ & $7.0 \pm 0.5$ & $984 \pm 89.76$ \\
\hline
\end{tabular}

Table 2. Below shows the serum value of Superoxide Dismutase, Glutathione Peroxidase and Catalase in the rabbits after 21 days of inducement with cortocosterone.

\begin{tabular}{lllll}
\hline Subjects & $\begin{array}{l}\text { Superoxide } \\
\text { Dismutase, }\end{array}$ & $\begin{array}{l}\text { Glutathione } \\
\text { Peroxidase }\end{array}$ & Catalase & $\begin{array}{l}\text { Weight } \\
\text { (grams) }\end{array}$ \\
\hline $\begin{array}{l}\text { Control Group A(Group not induced or } \\
\text { treated with extract) }\end{array}$ & $147 \pm 13.4$ & $198 \pm 8.2$ & $7.5 \pm 0.8$ & $1010 \pm 99.8$ \\
\hline $\begin{array}{l}\text { Group B induced for treatment with Aqueous } \\
\text { Extract }\end{array}$ & $140 \pm 6.2$ & $160 \pm 6.3$ & $4.0 \pm 0.3$ & $815 \pm 100$. \\
\hline $\begin{array}{l}\text { Group C induced for treatment } \\
\text { with ethanolic Extract }\end{array}$ & $124 \pm 7.3$ & $160 \pm 7.0$ & $4.5 \pm 0.6$ & $963 \pm 67.5$ \\
\hline
\end{tabular}


Table 3. Below shows the serum value of Superoxide Dismutase, Glutathione Peroxidase and Catalase in the rabbits treated for 21 days following 21 days of inducement with cortocosterone.

\begin{tabular}{|c|c|c|c|c|}
\hline Subjects & $\begin{array}{l}\text { Superoxide } \\
\text { dismutase, }\end{array}$ & $\begin{array}{l}\text { Glutathione } \\
\text { peroxidase }\end{array}$ & Catalase & $\begin{array}{l}\text { Weight } \\
\text { (grams) }\end{array}$ \\
\hline $\begin{array}{l}\text { Control Group } \mathrm{A}(\text { Group not induced or } \\
\text { treated with extract) }\end{array}$ & $147 \pm 13.4$ & $198 \pm 8.2$ & $7.5 \pm 0.8$ & $1001 \pm 101$ \\
\hline $\begin{array}{l}\text { Group B induced and treated with } \\
\text { Aqueous Extract }\end{array}$ & $161 \pm 17.2$ & $196 \pm 10$ & $6.9 \pm 1.0$ & $911 \pm 89$ \\
\hline $\begin{array}{l}\text { Group } \mathrm{C} \text { induced } \\
\text { with ethanolic Extract }\end{array}$ & $155 \pm 8.9$ & $199 \pm 9.3$ & $7.5 \pm 0.8$ & $1004 \pm 58$ \\
\hline
\end{tabular}

Table 4. Below shows the biochemical comparative of the inducement of oxidative stress and treatment with corn silk extract (aqueous and methanol).

\begin{tabular}{|c|c|c|c|c|c|c|c|}
\hline $\begin{array}{l}\text { Control/ } \\
\text { Test Croup } \\
\text { B before } \\
\text { inducement }\end{array}$ & $\begin{array}{l}\text { Control/ } \\
\text { Test Group } \\
\text { C before } \\
\text { inducement }\end{array}$ & $\begin{array}{l}\text { Control// } \\
\text { TEST } \\
\text { Croup B } \\
\text { after } \\
\text { inducement }\end{array}$ & $\begin{array}{l}\text { Control/ } \\
\text { Test Croup } \\
\text { C after } \\
\text { inducement }\end{array}$ & $\begin{array}{l}\text { Aqueous } \\
\text { Group B } \\
\text { before and } \\
\text { after } \\
\text { treatment }\end{array}$ & $\begin{array}{l}\text { Ethanolic } \\
\text { Group C } \\
\text { before } \\
\text { and after } \\
\text { treatment }\end{array}$ & $\begin{array}{l}\text { Group B } \\
\text { and C after } \\
\text { inducement }\end{array}$ & $\begin{array}{l}\text { Group B } \\
\text { and C } \\
\text { after } \\
\text { treatment }\end{array}$ \\
\hline
\end{tabular}

\begin{tabular}{|c|c|c|c|c|c|c|c|c|}
\hline & \multicolumn{8}{|c|}{ 't' value } \\
\hline $\begin{array}{l}\text { Superoxide } \\
\text { dismutase }\end{array}$ & 0.62 & 0.377 & 0.49 & 1.56 & 1.16 & 2.7 & 1.73 & 0.311 \\
\hline $\begin{array}{l}\text { Glutathione } \\
\text { peroxidase }\end{array}$ & 1.15 & 0.600 & 5.87 & 5.21 & 3.1 & 3.4 & 0 & 0.222 \\
\hline$\overline{\text { Catalase }}$ & 0.56 & 0.32 & 4.096 & 3.0 & 9.2 & 3.0 & 0.75 & 0.744 \\
\hline & \multicolumn{8}{|c|}{ 'p' value } \\
\hline $\begin{array}{l}\text { Superoxide } \\
\text { dismutase }\end{array}$ & 0.301 & 0.371 & 0.337 & 0.130 & 0.182 & 0.056 & 0.112 & 0.39 \\
\hline $\begin{array}{l}\text { Glutathione } \\
\text { peroxidase }\end{array}$ & 0.184 & 0.304 & $0.041^{* *}$ & $0.017^{* *}$ & $0.045^{* *}$ & $0.038^{* *}$ & 0.5 & 0.422 \\
\hline Catalase & 0.32 & 0.39 & $0.027^{* *}$ & $0.048^{* * k}$ & $0.006^{* *}$ & $0.048^{* * k}$ & 0.267 & 0.267 \\
\hline
\end{tabular}

\section{Discussion}

The result obtained showed a significantly lower mean plasma value of Glutathione peroxidase, Catalase in test Croup B and C after inducement with corticosterone compared with the control. This is consistent with the report of Zafir and Banu [11] that after a 21-day experimental period, a significant decline in both superoxide dismutase and catalase was observed in both stressed and stress hormone- treated (corticosterone) animals. The brain levels of glutathione as well as the activities of glutathione-S-transferase and glutathione reductase were also significantly decreased, while lipid peroxidation levels were significantly increased in comparison to controls. Corticosterone caused a small but significant decrease in GSPx activity over a range of glucose concentrations; this occurred under circumstances of an excess of glutathione as a substrate, suggesting a direct effect of 
corticosterone on GSPx [12]. Kolosova et al. [13] reported increase in corticosterone with a corresponding increase in lipid peroxidation. In many species, including amphibians, reptiles, rodents and birds, corticosterone is a main glucocorticoid, involved in regulation of energy, immune reactions, and stress responses [10]. These reports could be associated with the findings of this work with reference to responses of the rabbits to corticosterone administration with respect to significant biochemical alterations in catalase and glutathione peroxidase activities.

There was also a significantly higher mean plasma value of Glutathione peroxidase, Catalase in test Croup B and C after treatment with aqueous and methanolic extract of corn silk following inducement with corticosterone than before the treatment. The result obtained could be associated with the fact that, lipid peroxidation is a process generated naturally in small amounts in the body, mainly by the effect of several reactive oxygen species (hydroxyl radical, hydrogen peroxide etc.). The destruction of membrane lipids and the end-products of such lipid peroxidation reactions are especially dangerous for the viability of cells, even tissues which could be scavenged by enzymatic (catalase, superoxide dismutasse) and nonenzymatic (vitamins $A$ and $E$ ) natural antioxidant defence mechanisms that exist; resulting into maximum utilization of scavenging enzymes antioxidants such as

\section{References}

1. Newal CA, Anderson LA, Phillipson JD: Herbal Medicine: a Guide for Health-care Professionals. Edited by Newal CA. London, Pharmaceutical Press; 1996:90.

2. Hasanudin K, Hashim P, Mustafa S.Corn silk (Stigma maydis) in healthcare: a phytochemical and pharmacological review. Molecules. 2012 Aug 13;17(8):9697-715.. DOI: $10.3390 /$ molecules17089697

3. Fleming $\mathrm{T}$ : PDR ${ }^{\circledR}$ for Herbal Medicines ${ }^{\mathrm{TM}}$. Second edition. Edited by Fleming T. New catalase, glutathione peroxidase and superoxide dismutasse and vitamins (vitamin $\mathrm{A}$ and $\mathrm{E}$ ) $[1,2,7,8]$.

The findings could again be associated with the scavenging antioxidant activities of some phytochemicals in corn silk extract especially vitamins, alkaloids, saponins, terpenoids and flavonoids [1,2]. The biochemical function of glutathione peroxidase is to reduce lipid hydroperoxides to their corresponding alcohols and to reduce free hydrogen peroxide to $[7,8]$.

Catalase is a common enzyme found in nearly all living organisms exposed to oxygen (such as vegetables, fruit or animals). It catalyzes the decomposition of hydrogen peroxide to water and oxygen. It is a very important enzyme in protecting the cell from oxidative damage by reactive oxygen species (ROS) that may be produced as a result of oxidative stress [14]. There have been many reports on the biological activities of corn silk constituents. Methanol extracts of corn silk showed an antioxidative activity on the level of lipid peroxidation $[3,4]$.

\section{Conclusion}

The result revealed possible scavenging activities of methanolic and aqueous extract of corn silk with reference to significant biochemical alteration in the plasma activities of catalase and glutathione peroxidase.

Jersey, Medical Economics Company; 2000:224-225.

4. Zeringue HJ: Identification and effects of maize silk volatiles on cultures of Aspergillusflavus.JAgric Food Chem. 2000, 48:921-925. PubMed Abstract | Publisher Full Text OpenURL DOI: 10.1021/jf990061k

5. JianyouGuo, Tongjun Liu, Linna Han and Yongmei Liu The effects of corn silk on glycaemicmetabolismNutrition\&

Metabolism. 2009, 6:47. DOI: $\underline{10.1186 / 1743-7075-6-47}$ 
6. Velazquez, D.V.O., Xavier, H.S., Batista, J.E.M., de Castro-Chavas, C. Zea mays L. extracts modify glomerular function and potassium urinary excretion in conscious rats. Phytomedicine. 2005;12:363-369. DOI: 10.1016/j.phymed.2003.12.010

7. Epp O, Ladenstein R, Wendel A."The refined structure of the selenoenzyme glutathione peroxidase at $0.2-\mathrm{nm}$ resolution". Eur. J. Biochem. 1983: 133 (1): 51-69. PMID $6852035 . \quad$ DOI: $10.1111 / \mathrm{j} .1432-$ 1033.1983.tb07429.x

8. Muller FL, Lustgarten MS, Jang Y, Richardson A, Van Remmen H. "Trends in oxidative aging theories". Free Radical Biology \& Medicine. 2007: 43 (4): 477-503. PMID $17640558 . \quad$ DOI: 10.1016/j.freeradbiomed.2007.03.034

9. Bhabak KP, Mugesh G. "Functional mimics of glutathione peroxidase: bioinspired synthetic antioxidants". Accounts of Chemical Research. 2010: 43 (11): 1408-1419. PMID 20690615. DOI: 10.1021/ar100059g

10. R.A. Hill; H.L.J. Makin; D.N. Kirk; G.M. Murphy. Dictionary of Steroids. CRC Press. pp. 189-. ISBN 978-0-412-27060-4, 1991.
DOI: $10.1007 / 978-1-4899-3310-2$

11. Zafir A, Banu N. Induction of oxidative stress by restraint stress and corticosterone treatments in rats.Indian J Biochem Biophys. 2009 Feb;46(1):53-8.

12. Patel R, McIntosh L, McLaughlin J, Brooke S, Nimon V, Sapolsky R.Disruptive effects of glucocorticoids on glutathione peroxidase biochemistry in hippocampal cultures. J Neurochem. $2002 \quad$ Jul;82(1):118-25. DOI: 10.1046/j.1471-4159.2002.00948.X

13. N. G. Kolosova, G. M. Petrakova, and M. A. Gilinskii. Corticosterone and lipid peroxidation in rats after two exposures to cold. Bulletin of Experimental Biology and Medicine. March 1999, Volume 127, Issue 3, pp 236-239 DOI: 10.1007/BF02433342

14. Chelikani P, Fita I, Loewen PC. "Diversity of structures and properties among catalases". Cell. Mol. Life Sci. 2004: 61 (2): 192-208. PMID 14745498. DOI: $10.1007 / \mathrm{s} 00018-$ $\underline{003-3206-5}$ 